\title{
Furosemide Topical Gel CLS006
}

National Cancer Institute

\section{Source}

National Cancer Institute. Furosemide Topical Gel CLS006. NCI Thesaurus. Code

C153417.

A sulfamoylanthranilic acid derivative and loop diuretic, with potential antiviral activity. Upon topical administration, furosemide gel inhibits potassium influx by interacting with cell membrane ion co-transporter, $\mathrm{Na}+-\mathrm{K}+-2 \mathrm{Cl}$-co-transporter-1(NKCC1; SLC12A2). This may inhibit potassium influx and prevent the replication of DNA viruses, such as human papillomavirus (HPV), that rely on potassium for replication. 